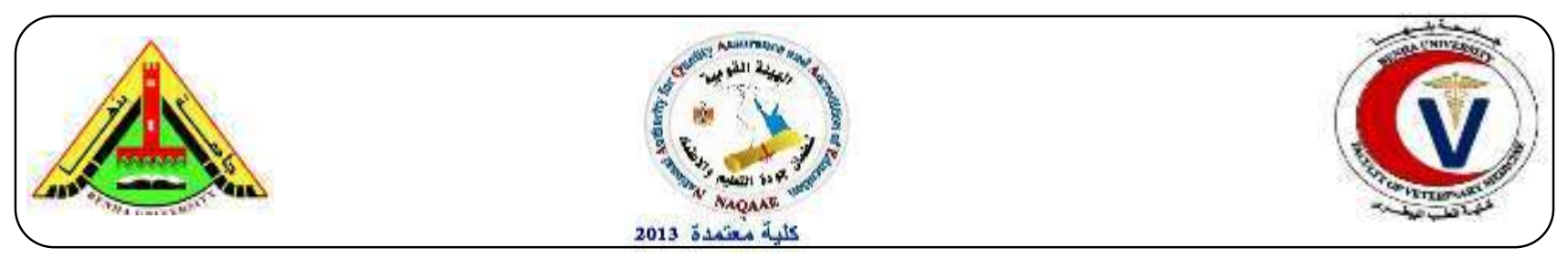

\title{
Effect of Synbiotics and Essential Oils in Ameliorating the Negative Drawbacks of Necrotic Enteritis and Coccidiosis in Broiler Chicks
}

\author{
Marwa Abdelhaleem, Amal Abdelnaser, Magda Ali
}

Department of Poultry Diseases and Management, Faculty of Veterinary Medicine, Benha University

\section{A B S T R A C T}

An experiment was conducted on 210 healthy one day old broiler chicks to evaluate the effect of synbiotics and/ or essential oils on induced necrotic enteritis (NE) and coccidiosis. The treated groups were, 1) ABAC group: challenged with Eimeria spp. $+C$. perfringens and fed basal diet with antibiotic and anticoccidial drugs; 2) SY group: challenged with Eimeria spp. $+C$. perfringens and fed basal diet with synbiotic; 3) EO group: challenged with Eimeria spp. $+C$. perfringens and fed basal diet with essential oils (EO); 4) SYEO group: challenged with Eimeria spp. $+C$. perfringens and fed basal diet with combination of synbiotics and essential oils; 5) CO group: fed basal diet and challenged with Eimeria spp.; 6) NE group: fed basal diet and challenged with Eimeria spp. $+C$. perfringens, and 7) $\mathrm{CN}$ group: fed basal diet. All additives were given from 0 day (d) to $35 \mathrm{~d}$. The results showed positive impact of synbiotic and EO treatments on lesion scoring and $C$. perfringens quantification in comparison with challenged non treated groups. The body weight did not show significant improvement $(\mathrm{P}>0.05)$ in $\mathrm{SY}$ group but the EO group increased the $\mathrm{BW}(\mathrm{P}>0.05)$. The treatments significantly decreased the oocyst shedding, dropping scoring and litter scoring against coccidiosis infection in comparison with $\mathrm{NE}$ group $(\mathrm{P}<0.05)$. The $\mathrm{ABAC}$ group showed insignificant decline in dropping and litter scoring in comparison with synbiotic and EO treatments $(\mathrm{P}>0.05)$. All treatments significantly improved the histopathological lesion scoring of intestine and liver as well as the coccidial infection score $(\mathrm{P}<0.05)$. Our data suggest that synbiotic and essential oils may be used as potential candidates for antibiotic and anticoccidial feed additives as they can promote better intestinal health.

Keywords: NE, Coccidiosis, Synbiotics, Essential oils, Broilers, Histopathology.

Received: 15 June 2019, Accepted: 18 August 2019 (http://www.bvmj.bu.edu.eg) (BVMJ-36(2): 187-198, 2019)

\section{INTRODUCTION}

Necrotic enteritis is an enterotoxemic multifactorial disease that destroys the intestinal lining of the digestive tract of both wild and domestic birds especially chickens used for meat production all over the world. Some toxins secreted from $C$. perfringens (Cp) types $\mathrm{A}$ and $\mathrm{C}$ are incriminated in the necrotic lesions in the intestinal wall and mortalities which in turn leads to high economic losses estimated to be more than $\$ 3$ billion/ year (Jayaraman et al., 2013). Coccidiosis is an enteric protozoal disease of poultry which caused by various Eimeria spp. The losses from this disease estimated by US $\$ 3$ billion / year around the world, which is mainly due to the cost of the anticoccidial 
feed additives, beside the death and the impaired growth of the affected birds (Shojadoost et al., 2012). The intercurrence between clostridioses and coccidioses is an increasing health risk to poultry (Shane, 2004). The antibiotics and anticoccidial feed additives have been used in preventing these enteric problems in the broiler industry for several years (Thomke and Elwinger, 1998). But since banning antibiotics in animal feeds in 2006 and questioning the health risks of using anticoccidial additives (Europe Union Commission, 2005), the necrotic enteritis outbreaks in broilers rearise at countries implied to the banning (Van Immerseel et al., 2004). Several recent studies have given main consideration to using probiotics (Dahiya et al., 2006), prebiotics (Branton et al., 1997) and EOytobiotics (Mitsch et al., 2004) as alternatives.

The probiotics are dietary supplements that consists of live microorganisms, which have good effect on the health of animal by enhancing the microbial balance (Fuller, 1989). Prebiotics are nondigestible shortlength carbohydrates that selectively stimulate the growth and / or activity of beneficial bacteria to improve the health of the host and suppress the harmful bacteria (Garcia, 2003). Combination between probiotics and prebiotics "synbiotic" aims for providing the host with beneficial bacteria and the fermentable substrate at the same time in order to guarantee the survival of this bacteria in the host and get advantages that each one offers (Fooks and Gibson, 2002).

The phytobiotics are natural new class of additives that based on herbs, spices and fruits. They enhance the productivity through improvement of digestibility, nutrient absorption and elimination of pathogens in the gut as well as, they have a high acceptability among consumers (Kubkomawa et al., 2013). The goal of this work is to evaluate the potential protective effects of synbiotic, essential oils (as a type of phytobiotics) and their combination as alternatives to antibiotic and the anticoccidial feed additives on induced NE and coccidiosis in broiler chicks.

\section{Materials and methods}

\subsection{Birds and management:}

The present experiment was conducted on 210, healthy one day old broiler chicks (Arbor Acres). Birds were fed on well-balanced diet formulated according to NRC, (1994) (Table 1). They were housed in a clean disinfected well ventilated room $(5 \mathrm{~m} \times 7 \mathrm{~m})$. The room was divided into 6 equal partitions for the first 6 groups (G1 - G6). The control group (G7) was housed in a separate place. The rooms were provided with suitable number of heaters, feeder and drinkers.

\subsection{Experimental design and NE induction:}

As shown in table 2, the experimental birds randomely divided into 7 groups (30 birds $/ 3$ replicates / group). The induction of necrotic enteritis was according to Gholamiandehkordi et al., (2007).

\subsection{Assessment of induced NE:}

\section{Body weight:}

The average body weight of chicks for each group was recorded at 35 day old (19 dpi).

Lesion scoring:

At 3 and 7 days after challenge 3 birds / group were euthanized and lesions on small intestine were scored 0-4 according to Prescott et al., (1978) as follow: 0: no gross lesions, normal intestinal appearance; $1=$ thin-walled or friable, gray appearance; 2: thin-walled, focal necrosis, gray appearance, small amounts of gas production; 3: thin walled, sizable patches of necrosis, gas-filled intestine, small flecks of blood; 4: severe extensive necrosis, marked hemorrhage, large amounts of gas in intestine. While, the pathologic alterations on liver were scored according to Jerzsele et al., (2012) as follow: $0=$ none, $1=$ mild lesions, $2=$ 
moderate lesions and $3=$ severe lesions. The cumulative score of each organ was obtained by summation the scores of this organ at 3 and 7 dpi (Hussain, 2006).

Quantification of C. perfringens:

The $\mathrm{Cp}$ quantification was carried out according to McReynolds et al., (2009). At 3 and $7 \mathrm{dpi}, 15 \mathrm{~cm}$ of jejunum cranial to Meckel's diverticulum was aseptically excised stomached for 30 seconds in $9 \mathrm{ml}$ fluid thioglycollate broth (Lab M L9-7J- UK). Ten-fold serial dilutions were performed, and then $1 \mathrm{ml}$ from each dilution was poured on tryptose sulfite cycloserine agar (Oxoid limited, Thermo Fisher Scientific Inc. UK). Plates incubated for $24 \mathrm{hrs}$ at $37^{\circ} \mathrm{C}$ under anaerobic conditions. Plates containing colonies exhibiting typical morphology with more than 30 or less than 300 colonies were counted and recorded.

\subsection{Assessment of coccidiosis:}

\section{Dropping scoring:}

The cumulative score of each group was obtained by summating the daily dropping scores recorded from 0 to 10 days post challenge with Eimeria spp. according to (Hussain, 2006). The daily dropping score was graded from 0-4, according to Morehouse and Barron, (1970) as follows: $0=$ normal color and consistency; $1=$ mild mucoid to watery droppings; 2- moderate mucoid to warery with abnormal colour; $3=$ all watery, bloody tinged color and $4=$ watery bloody droppings.

\section{Lesion scoring for coccidiosis:}

Three birds / group euthanized at $10^{\text {th }}$ dpi with Eimeria spp. to score small intestine parts (duodenum, jujenum and ilieum) and cecum for coccidial lesions according to Johnson and Reid (1970) as follow: $0=$ normal with no gross lesions, $1=$ small scattered petechiae, $2=$ numerous petechiae, $3=$ extensive hemorrhage and $4=$ extensive hemorrhage that gives a dark color to the cecal intestine. The cumulative score was obtained by summating the scores of intestinal parts for each group (Hussain, 2006).

Litter scoring:

On d 21 and 35, litter conditions were scored according to Abdelrahman et al., (2014) ) as follow: $0=$ dry, friable material throughout the pen, $1=$ predominantly dry material but with some evidence of crusting around drinkers and feeders, $2=$ litter material is mostly acceptable but with some areas of wet shavings or capped material, $3=$ poor quality litter material with a large proportion of wet areas and capping of the litter, $4=$ unacceptable litter quality, wet and capped but with a few areas of dry material remaining, $5=$ all litter is wet and soggy, no dry areas left. The cumulative score was calculated by summatin scores of both periods for each group according to (Hussain, 2006). Oocyst shedding:

Fresh fecal samples collected weekly (1-5 weeks) from each group. Microscopical count carried out according to Long et al., (1976), and represented as oocysts per gram of excreta. The cumulative shedding was calculated according to (Hussain, 2006).

\subsection{Histopathological examination:}

Small intestine, cecum and liver were collected 7 dpi with $C$. perfringens and preserved in $10 \%$ formalin solution then examined according to Bancroft et al., (1996). The histopathological changes in these organs were scored in from 0 to 4 as follow: 0: no lesions; 1: mild lesions; 2: moderate lesions; 3: severe lesions and 4: very severe lesions. The cumulative intestinal scoring and coccidial infection was calculated according to (Hussain, 2006).

\subsection{Statistical analysis:}

Differences between groups were analyzed by using One-Way ANOVA and Duncan's multiple comparison Post Hoc tests (Duncan, 1955).

\section{RESULTS}




\subsection{Parameters of induced NE:}

As shown in table 3, the EO and SYEO groups showed improvement $(\mathrm{P}>0.05)$ in $\mathrm{BW}$ $(1.34 \mathrm{Kg}$ and $1.23 \mathrm{Kg}$ respectively) in comparison with NE group $(1.20 \mathrm{Kg})$. However, these treatments were in significantly lower in weight in comparison with ABAC group $(1.40 \mathrm{Kg})$. The lowest BW recorded in $\mathrm{SY}$ group $(1.12 \mathrm{Kg})$ which was significant decline in comparison with the antibiotic treated group only $(\mathrm{P}<0.05)$.

The cumulative (cum.) scoring of small intestine (Plate 1) was significantly decreased $(\mathrm{P}<0.05)$ in SY group at 3 and 7 dpi (4 and 4.67 respectively) in comparison with $\mathrm{NE}$ group (8.33 and 8 respectively). In addition, the EO and SYEO groups recorded decrease in cumulative scoring, this decline in scoring was significant only in EO group at $3 \mathrm{dpi}$ (4.33) in comparison with NE group $(\mathrm{P}<0.05)$. The antibiotic treated group did not show significant improvement $(\mathrm{P}>0.05)$ more than other treatments at different periods. The liver of EO group recorded the lowest cumulative scoring (4.33) in all treatments and this score differed significantly from the score of $\mathrm{NE}$ group which was 8 (Plate 2).

The colony count values (represented as log 10) were significantly increased in NE group at 3 dpi (3.13) and at $7 \mathrm{dpi}$ (2.98) in comparison with the $\mathrm{CN}(0.96$ and 0.51 respectively) $(\mathrm{P}<0.05)$. The $\mathrm{SYEO}, \mathrm{SY}$ and EO groups showed decrease in number of $C$. perfringens colonies at $3 \mathrm{dpi}(2.66,2.53$ and 2.51 respectively) and $7 \mathrm{dpi}(2.23,1.46$ and 1.97 respectively) in comparison with the NE group (3.13 and 2.98) ( $\mathrm{P}>0.05)$. The ABAC group recorded insignificant decline of colony count $(\mathrm{P}>0.05)$ at 3 and 7 dpi (2.11 and 1.32 respectively) in comparison with SY, EO and SYEO treatments.

\subsection{Parameters of coccidiosis:}

From data shown in table 4 , the cumulative dropping scoring was significantly decreased $(\mathrm{P}<0.05)$ in all treated challenged birds (ranged from 8.67 to 10 ) in comparison with the NE group (17.67). The lowest cum. score (8.67) was recorded in SYEO and ABAC groups (Plate 3).

The cum. lesion scoring of intestine (Plate 1) was significantly declined $(\mathrm{P}<0.05)$ in SY, EO and SYEO groups (2.33, 2 and 4.33 respectively) in comparison with the $\mathrm{NE}$ group (6.67). Insignificant difference was recorded between cum. scoring of intestine $(\mathrm{P}>0.05)$ in ABAC group (1.67), SY and EO groups (Table 4).

The cum. litter score of treated groups was significantly declined in all treatments $(0$ for all, except SY group scored 0.33) $(\mathrm{P}<0.05)$ in comparison with the $\mathrm{CO}$ and $\mathrm{NE}$ groups (1 and 1.67).

The cumulative oocyst count was significantly increased in $\mathrm{CO}$ and $\mathrm{NE}$ group $\left(3.7 \times 10^{4}\right.$ and $3.0 \times 10^{4}$ respectively) $(\mathrm{P}<0.05)$ in comparison with the $\mathrm{CN}$ group (44.45). On the other hand, there was significant decline in the cum. shedding reported in SY, EO and SYEO groups $\left(1.40 \times 10^{4}, 1.4 \times 10^{4}\right.$ and $1.7 \times 10^{4}$ respectively) in comparison with $\mathrm{NE}$ group $(\mathrm{P}<0.05)$. Expectedly the lowest cum. count recorded in ABAC group (633.33) which was significant decline $(\mathrm{P}<0.05)$ in comparison with other treatments and +ve controls.

\subsection{Histopathological findings:}

The histopathological changes in intestine and liver of euthanized birds were listed in table 5 and plate 4 The NE group showed moderate to very sever histopathological changes in different intestinal sections and scored 10 in the cum. scoring of intestine. Also it showed significant increase in cum. coccidial infection (6) in comparison with the $\mathrm{CN}$ group which showed normal histological 
structure and unnoticeable coccidial infection (0.33) $(\mathrm{P}<0.05)$. The EO, SY and SYEO groups recorded low cum. intestinal scoring (7, 8 and 9 respectively) in comparison to $\mathrm{NE}$ group (10) as well as significant low cum. infection by coccidia $(1,2.33$ and 2 respectively) in comparison with both $\mathrm{CO}$ and NE group (6). As predictable the ABAC group recorded the lowest cum. infection and histopathological changes (1 and 6$)$ in comparison with NE group, but this decline was insignificant in comparison with synbiotic and EO groups $(\mathrm{P}>0.05)$. The EO, SY and ABAC groups showed mild (1) histopathological changes in liver in comparison with NE group which showed sever lesions (3).

Table1: Experimental design and different treatments.

\begin{tabular}{|c|c|c|c|c|c|c|}
\hline \multirow[t]{2}{*}{ Groups } & \multirow{2}{*}{$\begin{array}{l}\text { Antibacterial }^{\mathrm{a}} \\
\text { Anticoccidial }^{\mathrm{b}}\end{array}$} & \multirow{2}{*}{$\begin{array}{l}\text { Synbiotic }^{\mathrm{c}} \text {, } \\
\text { probiotic }^{\mathrm{d}}\end{array}$} & \multirow[t]{2}{*}{ Phytobiotic $^{\mathrm{e}}$} & \multicolumn{2}{|c|}{ Artificial infection } & \multirow{2}{*}{$\begin{array}{l}\text { IBD } \\
\text { vaccination }^{\wedge}\end{array}$} \\
\hline & & & & Eimeria spp. ${ }^{\wedge}$ & C. perfringens \# $^{\#}$ & \\
\hline Group 1 (ABAC) & + & - & - & + & + & + \\
\hline Group 2 (SY) & - & + & - & + & + & + \\
\hline Group 3 (EO) & - & - & + & + & + & + \\
\hline Group 4 (SYEO) & - & + & + & + & + & + \\
\hline Group 5 (CO) & - & - & - & + & - & + \\
\hline Group 6 (NE) & - & - & - & + & + & + \\
\hline Group 7 (CN) & - & - & - & - & - & - \\
\hline
\end{tabular}

a: chlortetracycline $\mathrm{Hcl}$ (1 kg/ ton feed /Atco pharma) for 35 days. ${ }^{\mathrm{b}}$ : diclazuril (200gm/ton feed /Atco pharma) for 35 days.

${ }^{\mathrm{c}}$ :Bacillus subtilis, B. licheniformis, Saccharomyces cerevisiae, beta glucan and mannanoligosccharides (250 gm/ton /organic chemical solutions, L.L.C. - USA) for 35 days. $\quad$ d. $5 \times 10^{12} \mathrm{CFU}$ of Enterococcus spp., Bifidobacterium spp., Pedicoccus spp. and Lactobacillus spp. (20 gm / 1000 bird / BIOMIN Singapore Pte Ltd) sprayed at hatchery only. ${ }^{\mathrm{e}}$ : essential oils of oregano, anise, and citrus peel (125 gm/ton/BIOMIN Singapore Pte Ltd). ^ : given at $12 \mathrm{~d}$ old; 10 -fold dose of commercial live attenuated coccidia vaccine (Coccivac $\mathrm{B}^{\mathrm{TM}}$ - Schering plaugh animal health) based on $E$. acervulina, E. maxima, E. Necatrix and E. tenella by oral route to mimic the detrimental effect of coccidiosis. ${ }^{\wedge}$ : $10^{5}$ of intermediate IBD virus (Cevac ${ }^{\mathrm{TM}}$ Gumbol - Ceva) given at 14 day old. ${ }^{\#}: 1 \mathrm{ml}$ of $4 \times 10^{8} \mathrm{cfu} / \mathrm{ml}$ of type A $\alpha$-toxigenic field strain of $C$. perfringens given at 17 day old for 3 successive days.

Table 2: Composition of starter, grower and finisher diets.

\begin{tabular}{llll}
\hline Ingredients & & $\%$ & \\
& Starter & Grower & Finisher \\
\hline Yellow corn & 53.85 & 58.40 & 61.24 \\
Soyabean meal 47 & 34.6 & 28.70 & 28.70 \\
Corn gluten meal & 4.15 & 5.00 & 1.65 \\
Vegetable oil & 2.50 & 3.40 & 4.40 \\
Sodium chloride & 0.30 & 0.30 & 0.30
\end{tabular}


Marwa et al. (2019). BVMJ-36(2): 187-198

\begin{tabular}{llll}
\hline DL-Methionine & 0.27 & 0.25 & 0.23 \\
L-Lysine & 0.22 & 0.35 & 0.12 \\
Limestone & 1.90 & 3.40 & 1.55 \\
mono-calcium EOosEOate & 1.43 & 1.20 & 1.10 \\
Sodium bicarbonate & 0.18 & 0.17 & 0.17 \\
Vit. and mineral premix & 0.30 & 0.30 & 0.30 \\
\hline
\end{tabular}

Table 3: Effect of antibiotic, synbiotic and essential oils on body weight $(\mathrm{Kg})$, lesion scoring and $\mathrm{Cp}$ count of experimental birds (means $\pm \mathrm{SE}$ ).

\begin{tabular}{|c|c|c|c|c|c|c|c|}
\hline Parameter & $\mathrm{ABAC}^{*}$ & $\mathrm{SY}^{*}$ & $\mathrm{EO}^{*}$ & SYEO* & $\mathrm{CO}^{*}$ & $\mathrm{NE}^{*}$ & $\mathrm{CN}^{*}$ \\
\hline BW & $1.40 \pm 0.04^{\mathrm{a}}$ & $1.12 \pm 0.11^{\mathrm{b}}$ & $1.34 \pm 0.04^{\mathrm{ab}}$ & $1.23 \pm 0.07^{\mathrm{ab}}$ & $1.31 \pm 0.12^{\mathrm{ab}}$ & $1.20 \pm 0.05^{\mathrm{ab}}$ & $1.41 \pm 0.01^{\mathrm{a}}$ \\
\hline \multicolumn{8}{|c|}{ Intestine cum. scoring } \\
\hline 3 dpi & $4.33 \pm 0.88^{\mathrm{bc}}$ & $4.00 \pm 0.57^{\mathrm{c}}$ & $4.33 \pm 0.88^{b c}$ & $6.33 \pm 0.67^{a b}$ & $2.33 \pm 0.33^{\mathrm{cd}}$ & $8.33 \pm 0.67^{\mathrm{a}}$ & $1.00 \pm 0.57^{\mathrm{d}}$ \\
\hline 7dpi & $4.67 \pm 0.33^{b}$ & $4.67 \pm 0.88^{b}$ & $5.67 \pm 1.45^{\mathrm{ab}}$ & $6.00 \pm 0.00^{\mathrm{ab}}$ & $4.67 \pm 0.88^{b}$ & $8.00 \pm 0.57^{\mathrm{a}}$ & $0.33 \pm 0.33^{\mathrm{c}}$ \\
\hline $\begin{array}{l}\text { Liver cum. } \\
\text { scoring }\end{array}$ & $5.33 \pm 0.88^{\mathrm{ab}}$ & $5.00 \pm 0.57^{\mathrm{ab}}$ & $4.33 \pm 0.88^{\mathrm{b}}$ & $5.00 \pm 0.57^{\mathrm{ab}}$ & $1.67 \pm 0.33^{\mathrm{c}}$ & $6.33 \pm 0.33^{\mathrm{a}}$ & $0.00 \pm 0.00^{\mathrm{c}}$ \\
\hline \multicolumn{8}{|c|}{ C. Perfringens count } \\
\hline 3dpi & $2.11 \pm 0.19^{b c}$ & $2.53 \pm 0.06^{\mathrm{ab}}$ & $2.51 \pm 0.07^{\mathrm{ab}}$ & $2.66 \pm 0.03^{a b}$ & $1.22 \pm 0.61^{\mathrm{cd}}$ & $3.13 \pm 0.05^{\mathrm{a}}$ & $0.96 \pm 0.48^{d}$ \\
\hline 7 dpi & $1.32 \pm 0.70^{\mathrm{bc}}$ & $1.46 \pm 0.73^{\mathrm{abc}}$ & $1.97 \pm 0.17^{\mathrm{abc}}$ & $2.23 \pm 0.06^{\mathrm{ab}}$ & $1.13 \pm 0.57^{\mathrm{bc}}$ & $2.98 \pm 0.03^{\mathrm{a}}$ & $0.51 \pm 0.51^{\mathrm{c}}$ \\
\hline
\end{tabular}

Duncan represents least significant differences between different groups at probability $\mathrm{P}<0.05$. Means with different superscripts (a, b, c, d) within a raw are significantly different at $\mathrm{P}<0.05$.

"ABAC: challenged and fed basal diet with antibiotic and anticoccidial drugs; SY: challenged and fed basal diet with synbiotic; EO:challenged and fed basal diet with essential oils; SYEO: challenged and fed basal diet with combination of synbiotics and essential oils; CO: fed basal diet and challenged with Eimeria spp.; NE: fed basal diet and challenged with Eimeria spp. + C. perfringens, and $\mathrm{CN}$ : fed basal diet

Table 4: Effect of antibiotic, probiotic, synbiotic and essential oils on cumulative scoring of dropping, lesion, litter and oocyst shedding (means $\pm \mathrm{SE}$ ).

\begin{tabular}{|c|c|c|c|c|c|c|c|}
\hline Parameter & $\mathrm{ABAC}^{*}$ & $\mathrm{SY}^{*}$ & $\mathrm{EO}^{*}$ & SYEO* & $\mathrm{CO}^{*}$ & $\mathrm{NE}^{*}$ & $\mathrm{CN}^{*}$ \\
\hline $\begin{array}{l}\text { Cum. } \\
\text { dropping }\end{array}$ & $8.67 \pm 0.67^{b}$ & $9.33 \pm 0.33^{b}$ & $10.00 \pm 0.58^{\mathrm{b}}$ & $8.67 \pm 0.88^{b}$ & $11.33 \pm 2.19^{b}$ & $17.67 \pm 1.86^{\mathrm{a}}$ & $2.00 \pm 0.00^{c}$ \\
\hline $\begin{array}{l}\text { crning } \\
\text { Cum. lesion } \\
\text { scoring }\end{array}$ & $1.67 \pm 0.67^{c}$ & $2.33 \pm 0.67^{\mathrm{c}}$ & $2.00 \pm 0.00^{\mathrm{c}}$ & $4.33 \pm 0.33^{b}$ & $3.00 \pm 0.58 \mathrm{bc}$ & $6.67 \pm 0.33^{\mathrm{a}}$ & $0.00 \pm 0.00^{\mathrm{d}}$ \\
\hline $\begin{array}{l}\text { Cum. litter } \\
\text { scoring }\end{array}$ & $0.00 \pm 0.00^{c}$ & $0.33 \pm 0.33^{c}$ & $0.00 \pm 0.00^{c}$ & $0.00 \pm 0.00^{\mathrm{c}}$ & $1.00 \pm 0.00^{\mathrm{b}}$ & $1.67 \pm 0.33^{\mathrm{a}}$ & $0.00 \pm 0.00^{\mathrm{c}}$ \\
\hline $\begin{array}{l}\text { scoring } \\
\text { Cum. oocyst } \\
\text { shedding }\end{array}$ & $633.33 \pm 183.588^{d}$ & $14000 \pm 2666.74^{c}$ & $14756 \pm 1118.26^{\mathrm{c}}$ & $17078 \pm 1578.83^{\circ}$ & $37367 \pm 1063.19^{\mathrm{a}}$ & $30322 \pm 3430.65^{b}$ & $44.45 \pm 22.22^{\mathrm{d}}$ \\
\hline
\end{tabular}

Duncan represents least significant differences between different groups at probability $\mathrm{P}<0.05$. Means with different superscripts $(\mathrm{a}, \mathrm{b}, \mathrm{c}, \mathrm{d})$ within a raw are significantly different at $\mathrm{P}<0.05$.

*ABAC: challenged and fed basal diet with antibiotic and anticoccidial drugs; SY: challenged and fed basal diet with synbiotic; EO:challenged and fed basal diet with essential oils; SYEO: challenged and fed basal diet with combination of synbiotics and essential oils; CO: fed basal diet and challenged with Eimeria spp.; NE: fed basal diet and challenged with Eimeria spp. + C. perfringens, and $\mathrm{CN}$ : fed basal diet 
Table 5: Effect of antibiotic, probiotic, synbiotic and essential oils on cum. histopathological coccidial infection (means \pm SE) and histopathological scoring of intestine and liver.

\begin{tabular}{|c|c|c|c|c|c|c|c|}
\hline $\begin{array}{l}\text { Organ/ } \\
\text { group }\end{array}$ & $\mathrm{ABAC}^{*}$ & $\mathrm{SY}^{*}$ & $\mathrm{EO}^{*}$ & SYEO $^{*}$ & $\mathrm{CO}^{*}$ & $\mathrm{NE}^{*}$ & $\mathrm{CN}^{*}$ \\
\hline $\begin{array}{l}\text { Cum. } \\
\text { intestinal } \\
\text { scoring }\end{array}$ & 6 & 8 & 7 & 9 & 9 & 10 & 0 \\
\hline Liver & 1 & 1 & 1 & 2 & 1 & 3 & 0 \\
\hline $\begin{array}{l}\text { Cum. } \\
\text { coccidial } \\
\text { infection }\end{array}$ & $1.00 \pm 0.58^{b}$ & $2.33 \pm 1.20^{\mathrm{b}}$ & $1.00 \pm 1.00^{\mathrm{b}}$ & $2.00 \pm 2.00^{\mathrm{b}}$ & $6.00 \pm 0.00^{\mathrm{a}}$ & $6.00 \pm 0.00^{\mathrm{a}}$ & $0.33 \pm 0.33^{b}$ \\
\hline
\end{tabular}

*ABAC: challenged and fed basal diet with antibiotic and anticoccidial drugs; SY: challenged and fed basal diet with synbiotic; EO:challenged and fed basal diet with essential oils; SYEO: challenged and fed basal diet with combination of synbiotics and essential oils; CO: fed basal diet and challenged with Eimeria spp.; NE: fed basal diet and challenged with Eimeria spp. + C. perfringens, and $\mathrm{CN}$ :fed basal diet
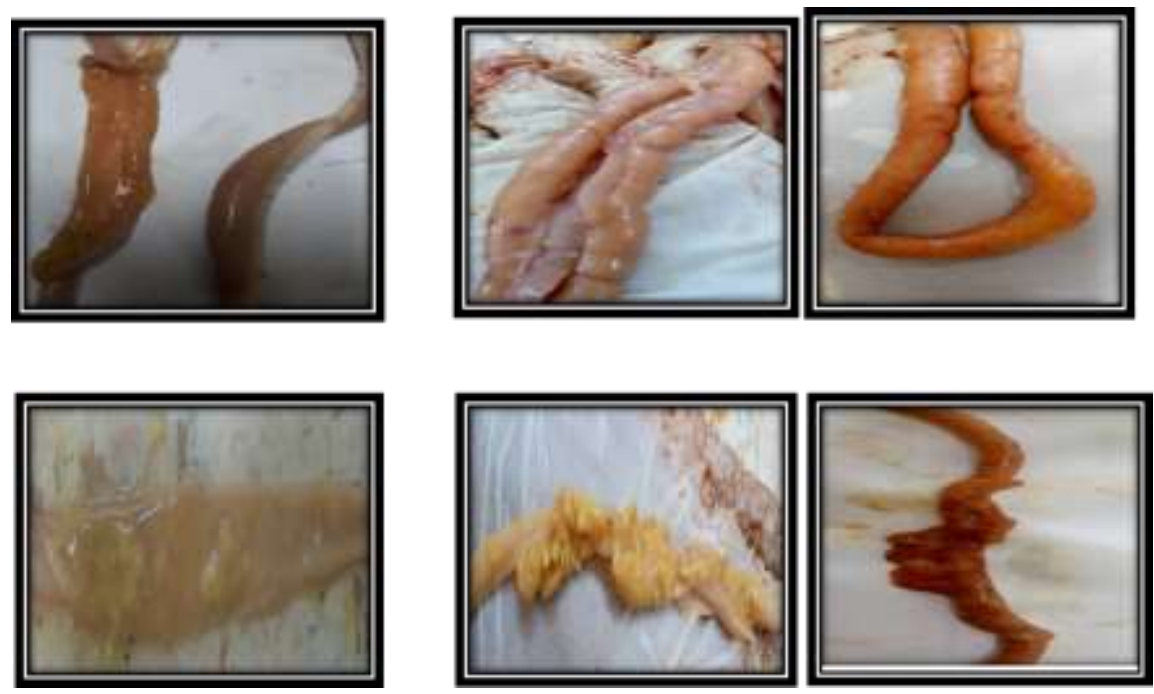

Plate.1. External and internal gross pathological changes in intestine of euthanized birds.

A-Small intestine of $\mathrm{CN}$ group showing normal external and internal anatomical picture.

B- Severe congestion, distention with numerous circumscribed hemorrhagic areas in duodenum of NE group

C-Congestion with dilation and few No. of circumscribed hemorrhagic areas on jujenum of SY group.

D-Paleness, thinning of wall with moderate amount of desquamated necrotized mucosa in jejunum of SY group.

E-Pale yellow undigested and unabsorbed feed particles mixed with necrotic mucosal depris in jejunum of NE group.

F-Severely hyperemic inflamed thickened mucosa with velvety appearance in jejunum of NE group. 

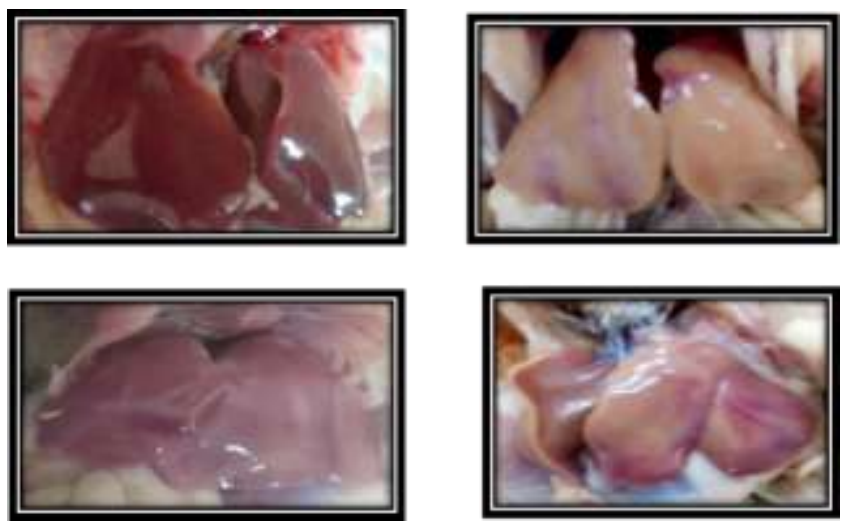

Plate.2. Gross pathological changes in liver of euthanized birds.

A-Normal anatomical picture of liver in $\mathrm{CN}$ group.

B-Paleness with longitudinal streaks of subcapsular hemorrhage in EO group.

C-Congestion with yellowish linear necrotic steaks in SYEO group.

D-Paleness with necrotic patches and subcapsular hemorrhage in NE group.
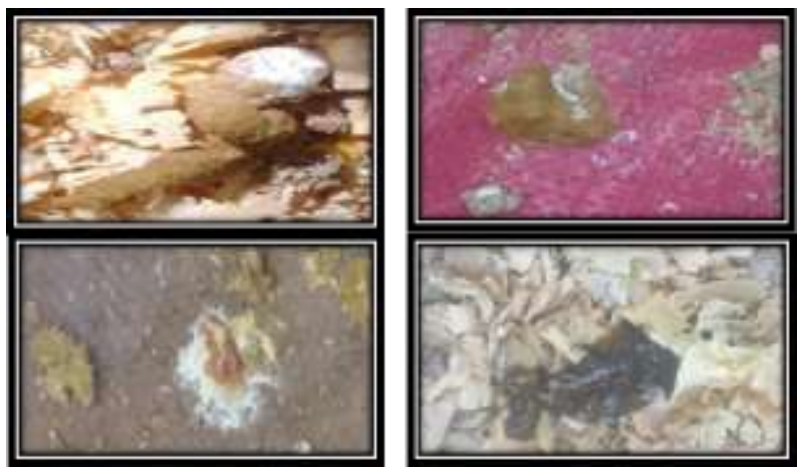

Plate.3. Changes in dropping of experimental birds.

A-Normal color and consistency of droppings in $\mathrm{CN}$ group.

B-Large amount of mucus in droppings with pale brown color in SYEO group.

C-Bloody droppings in $\mathrm{CO}$ group.

E-Watery dark brown to black droppings in NE group.
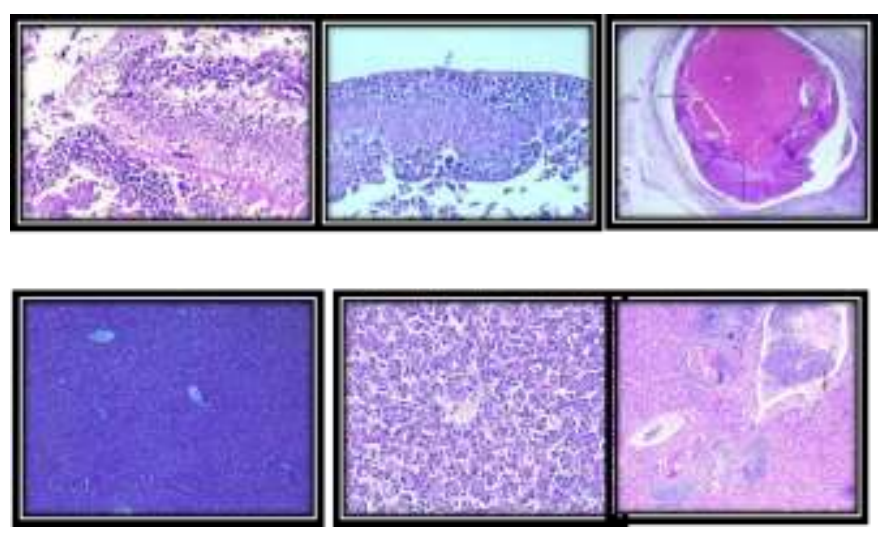

Plate.4. Histopathological changes in intestine and liver of euthanized birds. 


\section{DISCUSSION}

The use of dietary additives as synbiotics and essential oils are gaining momentum and paid an attention to be used as alternatives to antibiotics and anticoccidial drugs to prevent $\mathrm{NE}$ and coccidiosis in broilers. In this study, $\mathrm{Cp}$ challenged broilers fed essential oils of oregano, anise, and citrus peel alone or in combination with synbiotic for 35 days has resulted numerical increase in $\mathrm{BW}$ in comparison with the NE group; while, synbiotic did not enhance the BW in comparison with the +ve control group. These results come along with those of Jerzsele et al., (2012) who found that using essential oils improved the performance of challenged broilers contrary to probiotics which did not. The EO were found to improve the taste and feed palatability, stimulate the secretion of bile, mucus and saliva and improve the digestive enzymes activities (Alloui et al., 2014).

The $\mathrm{Cp}$ challenged birds showed increase in gross lesions on different parts of the small intestine and livers as well as increases the cfu of $\mathrm{Cp}$ in jejunum in comparison with the negative control group. Using synbiotic, essential oils and their combination in diets of $\mathrm{Cp}$ challenged broilers were very efficacious in reducing the severity of lesions in the small intestine and livers as well as the Cp count. Interestingly, chlortetracycline HCL/diclazuril treated group recorded insignificance $(\mathrm{P}>0.05)$ in values of scoring and microbiological count in comparison with the used biological treatments. These findings agreed with McReynolds et al., (2009) who reported that multistrain probiotic or essential oils in feed or water of $\mathrm{Cp}$ challenged broilers reduce lesion scoring and $\mathrm{Cp}$ count. $S$. cerevisiae and its cell wall extract were found to increase intestinal $\operatorname{IgA}$ production which binds to $C$. perfringens $\alpha$-toxin and prevent their passage through the mucosal membrane hence, no infection establishment and lesions in intestine (Kulkarni et al., 2010). EO can stimulate digestive enzymes as trypsin which inactivates the $\alpha$-toxin of $\mathrm{Cp}$ type $\mathrm{A}$ and the $\beta$ toxin of Cp type C (Baba et al., 1992).

The synbiotics, EO and their combination reduced lesion, litter and dropping scorings as well as oocyst shedding in challenged birds in comparison with the non-treated challenged groups. Birds receiving diclazuril in diet showed lower oocyst shedding than other treatments, but insignificant differences were recorded in other parameters in comparison with them. Similarly, using Lactobacillus spp. and /or MOS as well as EO reduced lesion scoring in challenged broilers with mixed Eimeria spp. (Bozkurt et al., 2014). The probiotic microorganisms can reduce the epithelial invasion by intracellular coccidia; hence decrease their multiplication and shedding (Abdelrahman et al., 2014). Moreover, presence of EO phenol compounds in EO disturb cellular ion balance, which results in cell membrane collapse and stop ATP synthesis in coccidian cell (Ultee et al., 1999). The recorded count of oocyst shedding in $\mathrm{CN}$ group can be attributed to uptake of oocysts from the surrounding environment as birds were kept on deep litter system.

Regarding to the recorded improvements in histopathological scoring and coccidial infection of synbiotic and EO treated birds, Al-Baadani et al., (2016) reported that supplementing $\mathrm{Cp}$ challenged broiler chicks with probiotics, prebiotics and synbiotics improved intestinal histopathological score and histomorEOometric criteria. Moreover, using essential oils in diets of broilers had significantly improved intestinal histopathological scores in challenged birds (Jerzsele et al., 2012).

\section{Conclusion}

According to our results, synbiotics and essential oils can be potential candidates as alternatives to antibacterial and anti coccidial 
drugs in poultry rations. As they ameliorated the negative drawbacks of necrotic enteritis and coccidiosis in broiler chickens by promoting better intestinal health. In addition, their using in diets will reduce the hazards associated with the antibiotic feed additives on both bird and human health.

\section{REFERENCES}

Abdelrahman,W.; Mohnl, M.; Teichmann, K.; Doupovec, B.; Schatzmayr, G.; Lumpkins, B. and Mathis G. 2014. Comparative evaluation of probiotic and salinomycin effects on performance and coccidiosis control in broiler chickens. Poultry Science 93:3002-3008

Al-Baadani, H.H.; Abudabos, A.M. and AlMufarrej S. I. 2016. Effects of dietary inclusion of probiotics, prebiotics and synbiotics on intestinal histological changes in challenged broiler chickens. South African Journal of Animal Science 46:57-165.

Alloui, M. N.; Agabou, A. and Alloui, N. 2014. Application of herbs and phytogenic feed additives in poultry production-A Review. Global Journal of Animal Scientific Research, 2(3):234-243.

Baba, E.; Wakeshima, H.; Fukui, K.; Fukata, T. and Arakawa A. 1992. Adhesion of bacteria to the cecal mucosal surface of conventional and germ-free chickens infected with Eimeria tenella. Am. J. Vet. Res, 53:194-197.

Banchroft, J.D.; Stevens, A.; and Turner, D.R. 1996. Theory and practice of histopathological techniques. Fourth Ed. Churchil Livingstone, New York, London, San Francisco, Tokyo.
Bozkurt , M.; Aysul , N.; Kucukyilmaz , K.; Aypak , S.; Ege, G.; Catli, A.U.; Akşit, H.; Coven, F.; Seyrek, K. and Cinar, M. 2014. Efficacy of in-feed preparations of an anticoccidial, multi enzyme, prebiotic, probiotic, and herbal essential oil mixture in healthy and Eimeria spp.-infected broilers. Poultry Science 93:389-399.

Branton, S.L.; Lott, B.D.; Deaton, J.W.; Maslin, W. R.; Austin, F.W.; Pote, L.M.; Keirs, R.W. ; Latour, M.A. and Day E.J. 1997. The effect of added complex carbohydrates added dietary fiber on necrotic enteritis lesions in broiler chickens. Poult. Sci, 76:24-28.

Dahiya, J.P.; Wilkie, D.C.; Van Kessel, A.G. and Drew M.D. 2006. Potential strategies for controlling necrotic enteritis in broiler chickens in postantibiotic era. Anim. Feed Sci. Technol, 129: 60-88.

Duncan, D.B. 1955. Multiple range and multiple $F$ tests. Biometrics 11:1-42.

Europe Union Commission 2005. Ban on antibiotics as growth promoters in animal feed enters into effect. Regulation 1831/2003/EC on additives for use in animal nutrition, replacing Directive 70/524/EEC on additives in feed-stuffs, Brussels, 22 December.

Fooks, L. J. and Gibson, G. R. 2002. Probiotics as modulators of the gut flora. British journal of nutrition, 88(1): 39-49.

Fuller, R. 1989. Probiotics in man and animals. J. Appl. Bacteriol, 66:365378.

García, L. H. 2003. Simposium: Probiotics and prebiotics. Biotecnología Aplicada, Vol.20, No.3. 
Gholamiandehkordi, A.R.; Timbermont, L.; Lanckriet, A.; Van Den Broeck, W.; Pedersen, K.; Dewulf, J.; Pasmans, F.; Haesebrouck, F.; Ducatelle, R.; and Van Immerseel, F. 2007. Quantification of gut lesions in subclinical necrotic enteritis. Avian Pathol, 36:375-382.

Hussein, Z. (2006): Aflatoxicosis in chicken: an inter-relationship between pathology, dietary and tissue aflatoxin levels. $\mathrm{PhD}$ degree thesis, Fac, of Vet. Sci, University of agriculture, Faisalabad, Pakistan

Jayaraman, S.; Thangave, G.; Kurian, H.; Mani, R.; Mukkalil, R.;and Chirakkal, H. 2013. Bacillus subtilis PB6 improves intestinal health of broiler chickens challenged with Clostridium perfringens-induced necrotic enteritis. Poultry Science 92:370-374.

Jerzsele, A.; Szeker, K.; Csizinszky, R.; Gere, E.; Jakab, C.; Mallo, J. J.; and Galfi, P. 2012. Efficacy of protected sodium butyrate, a protected blend of essential oils, their combination, and Bacillus amyloliquefaciens spore suspension against artificially induced necrotic enteritis in broilers. Poultry Science, 91:837-843

Johnson, J., and Reid, W. M. 1970. Anticoccidial drugs: Lesion scoring techniques in battery and floor-pen experiments with chickens. Exp. Parasitol, 28:30-36.

Kubkomawa, H.I.; Nafarnda, D.W.; Mukang, S.M.; Tizhe, M.A.; Tuakam, D.K.; Shua, N.J.; Ugwu, C.C.; Opara, M.N.; Neils, J.S.; Okoli, I.C. 2013. Ethnoveterinary health management practices amongst livestock producers in Africa - A review. World J. Agri. Sci. 1(8):252-257.
Kulkarni, R. R.; Parreira, V.R.; Jiang, Y.F.; and Prescott, J.F. 2010. A live oral recombinant Salmonella enterica serovar Typhimurium vaccine expressing Clostridium perfringens antigens confers protection against necrotic enteritis in broiler chickens. Clin. Vaccine Immunol. 17:205-214.

Long J.R. and Truscott, R.B. 1976. Necrotic enteritis in broiler chickens. III. Reproduction of the disease. Can J Comp Med, 40:53-59.

McReynolds, J.; Waneck, C.; Byrd, J.; Genovese, K.; Duke, S. and Nisbet, D. 2009. Efficacy of multistrain direct-fed microbial and phytogenetic products in reducing necrotic enteritis in commercial broilers. Poultry Science 88:2075-2080.

Mitsch, P.; Zitterl-Eglseer, KKohler, B.; Gabler, C.; Losa, R. and Zimpernik I. 2004. The effect of two different blends of essential oil components on the proliferation of Clostridium perfringens in the intestines of broiler chicken. Poult. Sci., 83:669-675.

Morehouse, N.F.; and Barron, R.R. 1970. Coccidiosis: evaluation of coccidiostats by mortality, weight gains and fecal score. Exp Parasitol, 28: 25-29.

National Research Council (NRC) 1994. Nutrient requirements of poultry. Ninth Ed, Washington, DC National academy press.

Prescott, J.F. 1979. The prevention of the experimentally induced NE in chickens by avoparcin. Avian Dis., 23:10721074.

Shane, S. M. 2004. Clostridial diseases limit production efficiency in antibiotic-free broiler flocks. Poult. Int, 43:12-13. 
Shojadoost, B.: Vince, A.R.; and Prescott, J.F. 2012. The successful experimental induction of necrotic enteritis in chickens by Clostridium perfringens: a critical review. Veterinary Research, 43:74.

Thomke, S. and K. Elwinger, 1998. Growth promotants in feeding pigs and poultry. II. Mode of action of antibiotic growth promotants. Ann. Zootech., 47:153167.
Ultee, A.; Kets, E. P. and Smid, E. J. 1999. Mechanisms of action of carvacrol on the food borne pathogen Bacillus cereus. Appl Environment Microbiol. 65:4606-4610.

Van Immerseel, F.; De Buck, J.; Pasmans, F.; Huyghebaert, G.; Haesebrouck, F.; Ducatelle R. 2004. Clostridium perfringens in poultry: an emerging threat for animal and public health. Avian Pathol, 33:537-549. 